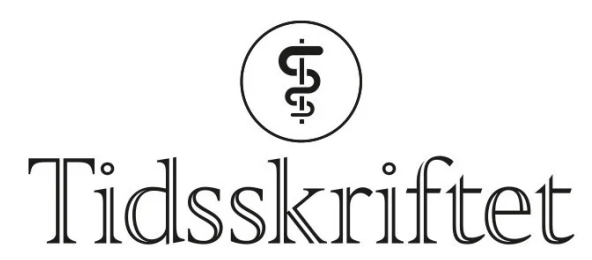

DEN NORSKE LEGEFORENING

\title{
Genetisk veiledning ved medfødt lang QT-syndrom
}

AKTUELT

\section{ANNIKEN HAMANG}

Email: anniken.hamang@isf.uib.no

Senter for medisinsk genetikk og molekylærmedisin Haukeland universitetssykehus

5021 Bergen

og

Institutt for samfunnsmedisinske fag

Universitetet i Bergen

\section{BERGE SOLBERG}

Institutt for sosialt arbeid og helsevitenskap Norges teknisk-naturvitenskapelige universitet

\section{CATHRINE BJORVATN}

Senter for medisinsk genetikk og molekylærmedisin Haukeland universitetssykehus

og

Institutt for samfunnsmedisinske fag

Universitetet i Bergen

\section{GOTTFRIED GREVE}

Hjerteavdelingen og Barneklinikken

Haukeland universitetssykehus

og

Institutt for klinisk medisin

Universitetet i Bergen

\section{NINA ØYEN}

Senter for medisinsk genetikk og molekylærmedisin Haukeland universitetssykehus

og

Institutt for samfunnsmedisinske fag

Universitetet i Bergen 
Medfødt lang QT-syndrom er en arvelig hjerterytmeforstyrrelse som gir økt risiko for ventrikkeltakykardi og plutselig død. Det finnes mulighet for diagnostisk og prediktiv gentesting.

MATERIALE OG METODE,

Artikkelen bygger på en omskrevet kasuistikk med en familie som er rammet av lang QTsyndrom, forfatternes erfaring innen fagområdet og søk i PubMed for perioden 1957-2007.

RESULTATER.

Kjennskap til genetisk risiko for plutselig død i familien kan iverksette tiltak som f.eks. genetisk testing og forebyggende behandling av barn, men kan også ha store psykososiale og etiske konsekvenser for familien og for helsepersonell som er involvert. For å illustrere dette bruker vi sykehistorien til en åtte år gammel gutt som besvimte på et idrettstevne. Hendelsen førte til medisinsk-genetisk utredning av førstegrads- og andregradsslektninger.

FORTOLKNING.

Problemstillinger rundt det å leve med risiko kan være svært belastende for individet og den øvrige familie, og bioteknologiloven som regulerer medisinsk-genetisk virksomhet er omfattende. Et viktig spørsmål er om det ut fra dagens lovverk er anledning til å oppsøke familiemedlemmer med genetisk risikoinformasjon.

I nær fremtid vil samfunnet og helsevesenet stå overfor store utfordringer når det gjelder å yte hjelp til stadig nye pasientgrupper der man på grunn av hurtig utvikling innen genteknologi kan bestemme genetisk overført sykdomsrisiko. Pasienter med medfødt lang QT-syndrom og deres familier er en gruppe hvor gentesting allerede har betydning for så vel diagnostikk som for forebygging og behandling. I Norge har vi siden 2001 hatt et tilbud om genetisk veiledning og medisinsk-genetisk utredning til disse pasientene og deres familier. Veiledning og oppfølging av pasienter med lang QT-syndrom reguleres av bioteknologiloven fra $2003(\underline{1})$.

\section{Materiale og metode}

Artikkelen bygger på en omskrevet kasuistikk og forfatternes erfaring innen fagområdet. Relevant litteratur er funnet ved søk i databasen PubMed i tidsperioden 1957-2007.

\section{ETIOLOGI}

Lang QT-syndrom er en arvelig hjerterytmeforstyrrelse. Tilstanden følger en autosomalt dominant arvegang med svært varierende penetrans (Romano-Wards syndrom). I tillegg finnes det en mer sjelden recessiv form, Jervell og Lange-Nielsens syndrom med hørselshemning som tilleggsymptom (2)-(4). Det er blitt identifisert hundrevis av mutasjoner i ti forskjellige gener som er blitt knyttet til lang QT-syndrom. Mutasjon i fem av genene (KCNQ1, HERG, SCN5A, minK, MiRP1) er årsak til de fleste tilfellene. Genene koder for ionekanaler som er viktige for hjertets repolarisering. Man kan til en viss grad knytte mutasjoner i de ulike genene til fenotypiske variasjoner av tilstanden (LOT1, LQT2, LQT3, LQT5 og LQT6) (5).

\section{SYMPTOMER OG DIAGNOSTIKK}

Ved lang QT-syndrom kan man ha forhøyet risiko for synkope, arytmi, ventrikkeltakykardi og plutselig død (ㅁ). Sykdommen rammer i første rekke barn og unge voksne, men symptomer kan manifestere seg fra første leveår opp til 50-6o års alder (7.). Diagnosen stilles etter bestemte diagnostiske kriterier. Symptomer som besvimelse, bradykardi og hørselshemning, EKG-forandringer som forlenget QT-tid, ventrikkeltakykardi (torsades de pointes), T-takkalternans og pukling av T-takken, og plutselig død eller kjent lang QTsyndrom i nær familie gis poeng som brukes til å gradere sannsynligheten til høy, middels og lav (요). Som ledd i denne diagnostiske utredningen kan pasienter i dag få sekvensert fem 
gener assosiert med sykdommen (9). En presis molekylærgenetisk diagnose gir til en viss grad behandlingsmuligheter tilpasset de ulike genmutasjonene (므), og er viktig for å påvise eller utelukke tilstanden hos familiemedlemmer (5). Timing og hyppighet av

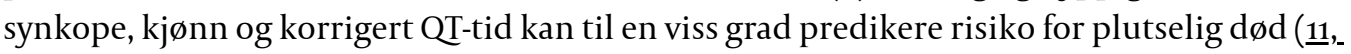
12). Man regner med at ubehandlet vil 6-13\% få hjertestans eller $\mathrm{d} \emptyset$ plutselig innen fylte 40 år (13), og hos ca. 10 \% av barn med tilstanden vil det ikke være noen kliniske manifestasjoner forut for plutselig død (14).). Det å ha blitt resuscitert etter hjertestans antas også å gi en større risiko for hjertehendelser (15). Det er også holdepunkter for at

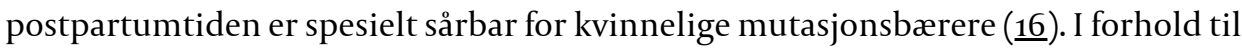
forebygging og behandling er det utarbeidet internasjonale retningslinjer (17.) (ramme 1 og 2).

\section{Ramme 1}

FOREBYGGING OG LEVEREGLER VED LANG QT-SYNDROM

- Unngå konkurranseidrett

- Unngå «risiko»-medikamenter (Pasienter og behandlende lege/fastlege bør utstyres med en medikamentliste over medikamentene som finnes på http://qtdrugs.org/)

- Begrense dykking og svømming eller aldri dykke/svømme alene

- Unngå å bli utsatt for høye lyder, spesielt under søvn og hvile, f.eks. fjern telefon og alarmklokke fra nattbordet

\section{Ramme 2}

\section{ANBEFALT BEHANDLINGSSTRATEGI VED LANG QT-SYNDROM ${ }^{1}$}

Klasse $^{2} 1$

- 1. Livsstilsendringer uansett klinisk og/eller molekylærgenetisk diagnose $(\mathrm{B})^{3}$

- 2. Betablokkere ved klinisk diagnose (B)

- 3. Intern defibrillator (ICD) sammen med betablokkere for pasienter som har overlevd hjertestans (A)

Klasse 2a

- 1. Betablokkere kan vurderes for å forebygge plutselig død hos mutasjonsbærere med normal QT-tid (B)

- 2. Intern defibrillator (ICD) sammen med betablokkere kan vurderes for å forebygge plutselig død hos pasienter som har besvimelser og/eller takykardier på tross av behandling med betablokkere (B)

Klasse $2 b$

- 1. Denervering kan vurderes for pasienter med besvimelser, torsades de pointes eller hjertestans for pasienter selv under behandling med betablokkere (B) - 2. Intern defibrillator (ICD) sammen med betablokkere kan vurderes for å forebygge plutselig død i kategorier som er assosiert med høyere risiko f. eks. LQT 1 og $2(\mathrm{~B})$ 
${ }^{1}$ Ifølge retningslinjer fra the American College of Cardiology, the American Heart Association and the European Society of Cardiology, i samarbeid med European Heart Rythm Association and the Heart Rythm Society (17.)

${ }^{2}$ Klasse 1 for tilstander som det er evidens for eller allmenn enighet om at prosedyre eller behandling er nødvendig, nyttig og effektivt. Klasse 2 for tilstander hvor det er motstridende evidens eller oppfatning om at behandling er nødvendig, nyttig og effektivt, hvor za heller i retning av at prosedyre /behandling er nødvendig, nyttig og effektivt, og hvor $2 \mathrm{~b}$ ikke har så sterk evidens for det

${ }^{3}$ Nivå av evidens er anmerket i klammer, hvor A betyr at data er fra randomiserte, kontrollerte forsøk eller metaanalyser, og hvor B betyr at data er fra en enkelt randomisert studie eller fra ikke-randomiserte studier

\section{GENETISK VEILEDNING}

I den genetiske veiledningen av pasienter med lang QT-syndrom blir det gitt informasjon om pasientens og familiemedlemmers eventuelle hjertesykdom og hjertesymptomer, samt hjertesykdommens forekomst, kliniske bilde, prognose, risikofaktorer, arvegang, gener, mutasjoner og behandlingsprinsipper. Fordeler og begrensninger ved gentest vektlegges særlig. Det kan også være relevant å diskutere temaer som yrkesvalg og utdanning, sportslige aktiviteter, sertifikater og forsikringsanliggender i veiledningen, fordi dette er områder som et positivt gentestsvar kan få konsekvenser og sette begrensninger for. Når man går igjennom familiehistorien og forklarer arvegang, blir det også tydelig hvem andre i familien som kan ha risiko og som har tilbud om gentesting. Fordi tilstanden innebærer risiko for plutselig død og dessuten kan være arvelig, er tilbudet om genetisk veiledning og testing utvidet til familiemedlemmer som i utgangspunktet er friske (prediktiv gentest). I kjølvannet av mulighetene for prediktiv gentesting av familiemedlemmer kommer også problemstillinger som har med psykososiale og etiske konsekvenser av den nye genteknologien mer til syne.

Kjennskap til genetisk risiko for plutselig død i familien kan føre til tiltak som f.eks. genetisk testing og forebyggende behandling av barn, men kan også få andre store psykososiale og etiske konsekvenser. På individnivå vil det være problemstillinger rundt det å leve med risiko, noe som kan være svært psykologisk belastende. Dødsfallene er ofte plutselige og dramatiske og kan påvirke familiemedlemmenes relasjon til hverandre. Det er ikke uvanlig å se forsvarsreaksjoner som fornekting og fortrenging eller sterk skyldfølelse for å ha gitt videre en genfeil. Noen ganger opplever man også at individer vil skåne eller hindre andre slektninger fra å vite om det. I slike tilfeller kan behandlende instans settes i en situasjon hvor oppsøkende genetisk informasjonsvirksomhet må vurderes, dvs. at intetanende slektninger blir oppsøkt og informert om sin eventuelle risiko.

Vi har i Norge lang tradisjon for genetisk veiledning. Dette startet allerede flere tiår før genetisk veiledning ble hjemlet i den første bioteknologiloven av 1994. Genetisk veiledning kan ses på som en prosess hvor man prøver å hjelpe pasienten med å forstå og tilpasse seg de medisinske, psykologiske og familiære konsekvensene av en arvelig sykdom (묘). Mange genetiske veiledningssamtaler ender i en valgsituasjon som f.eks.: "Ønsker jeg å foreta en gentest som sier noe om min risiko for å utvikle en sykdom?» Mange av valgene er både av eksistensiell og av irreversibel karakter. Målet med veiledningssamtalene er å hjelpe pasientene til å sortere sine tanker rundt valgene og falle ned på den beslutningen som passer best for dem. Dette avspeiler også intensjonen i bioteknologiloven om et reelt informert samtykke.

I genetisk veiledning av pasienter med lang QT-syndrom og deres familiemedlemmer har vi møtt store utfordringer. I kasuistikken beskrives en pasient, men den er helt omskrevet, anonymisert og ikke lenger gjenkjennbar. Historien omhandler hendelsesforløpet i en 
familie som er rammet av dette syndromet og hvor problemstillingene genetisk testing av barn og oppsøkende genetisk informasjonsvirksomhet blir diskutert i lys av bioteknologiloven fra 2004 (1).

\section{Kasuistikk}

En åtte år gammel gutt besvimte på et idrettsstevne, og ved undersøkelse ble det funnet forlenget QT-tid målt i EKG. Gutten har siden den gang vegret seg for å la seg medisinere med betablokker. Han sier han blir så trett og sliten, særlig i forbindelse med aktivitet. Søsteren, som er 14 år, har foreløpig ikke hatt besvimelser og har nektet å la seg behandle med betablokker fordi hun er en lovende idrettsutøver. Mor og far ønsker at barna skal gentestes og familien er henvist til medisinsk-genetisk avdeling fra barnekardiolog.

Genetisk veiledning blir gitt til familien i forbindelse med testing, samtykkeerklæring blir underskrevet av begge foreldrene. Vi velger å gi de to barna en kortversjon av den genetiske veiledningssamtalen, samt å informere dem om at det er foreldrene som har ønsket å genteste dem.

En tid senere foreligger gentestsvaret og det er kun mor som kommer for å få svaret. Det er ikke påvist genfeil hos henne. Da far ikke er til stede, konsentreres informasjon vedrørende barna som begge har fått påvist feil i ett av lang QT-syndrom-genene. Vi tilbyr familien og spesielt far en ny avtale dersom far er interessert i å få formidlet gentestsvaret. Vi vil ikke ta kontakt med ham ytterligere utover det vi har gjort hittil, da vi får signaler om at han angrer på at gentestingen ble utført. I tillegg får vi opplysninger om at han føler at det er vanskelig å informere familien, da søskenflokken hans er splittet pga. en familiekonflikt.

Mor gjør oss oppmerksom på at hennes ektefelles søster venter sitt førstefødte barn med termin om to måneder. Dersom far kontakter oss og får formidlet svaret, vil vi kunne tilby hans søster gentesting.

Det går flere dager uten at far tar kontakt. Vi er urolige for ikke å kunne nå den gravide søsteren. Vi frykter at far vegrer seg for å snakke med henne, da det ikke har vært kontakt mellom dem på mange år pga. familiekonflikten. Det vil være å foretrekke at far selv orienterer sin søster om situasjonen. Dersom det ikke lar seg gjøre, blir det diskutert om vi kan benytte oppsøkende genetisk informasjonsvirksomhet i henhold til bioteknologiloven for å nå hans søster og få orientert henne om familiens sykdom.

Vi blir enige om at vi kontakter mor på nytt for å høre hvordan det går. Noen dager senere kontakter far oss. Han ønsker å få formidlet sitt testresultat. Han har samme genfeil som sine barn. Videre får han tilbud om genetisk veiledning og kardiologisk oppfølging. Han blir informert om at det kan være aktuelt med behandling, og at det er noe ansvarlig kardiolog må vurdere ut fra hans gentestresultat, samt faktorer som alder, symptomer og ev. funn i hjerteundersøkelse. Vi får tillatelse til å kontakte hans søster. Han gir oss også tillatelse til å oppgi mutasjonsfunnet hans. Imidlertid ønsker han på slutten av samtalen selv å kontakte sin søster. Søsteren kan så ta kontakt med oss dersom hun ønsker videre utredning.

Saken blir avklart ved at søsteren henvender seg og man slipper å vurdere oppsøkende genetisk informasjonsvirksomhet. Det viser seg etter genetisk testing at hun ikke har arvet mutasjonen. Det er dermed ikke grunn til særlige hensyn i forbindelse med fødsel og postpartumtiden i dette tilfellet.

\section{Diskusjon}

Hva sier loven om genetisk undersøkelse av barn i denne forbindelse? Genetiske prediktive undersøkelser skal ikke utføres før barnet er fylt 16 år med mindre unders $\varnothing$ kelsen kan påvise forhold som ved behandling kan forhindre eller redusere helseskade hos barnet. 
Dersom den som undersøkes er et barn under 16 år, skal genetisk veiledning også gis til barnets foreldre eller andre med foreldreansvar.

Lang QT-syndrom er en sykdom som først og fremst rammer barn og unge og hvor det er mulig å forebygge livstruende symptomer med leveregler og medikamentell behandling (ramme 1 og 2). Syndromet vil således være en av sykdommene det kan være anledning til å gjøre prediktiv gentesting av barn under 16 år. Et gentestsvar vil imidlertid bare si noe om bærerstatus, men ikke hvorvidt man vil få symptomer i livsløpet. Fra kardiologisk synspunkt vil den varierende penetransen være en utfordring når man skal ta stilling til medikamentell behandling. Mutasjonsbærere kan mangle eller ha symptomer og ha normal eller forlenget QT-tid i EKG. Mye tyder på at mutasjonsbærere uansett funn bør

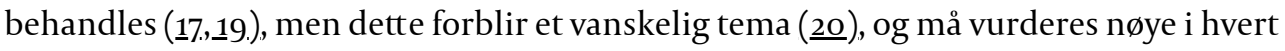
enkelt tilfelle. Man kjenner til at betablokkere gir risikoreduksjon for hjertehendelser (15), men behandling med betablokkere gir også visse bivirkninger som kan få innvirkning på pasientenes livskvalitet. Noen av dem som kommer til å bli behandlet, ville kanskje aldri fått kliniske symptomer.

Kunnskap om bærerstatus vil kunne få innvirkning på viktige livsvalg som yrke, attføring, graviditet eller utøvelse av konkurransesport, samt leveregler for å unngå triggersituasjoner for hjerterytmeforstyrrelser. Et spørsmål vil da være om det er hensiktsmessig å påføre en slik potensiell belastning på barn, før de egentlig kan gi et reelt samtykke til det. På den andre siden vet vi at dette kan være en svært alvorlig tilstand, hvor plutselig død kan være første kliniske manifestasjon, og det er også sannsynlig at barn uansett vil måtte leve med denne risikoen hvis tilstanden er kjent i familien. Det kan da tenkes at et gentestsvar vil være av positiv verdi - både fordi usikkerhet ofte oppleves verre enn sikkerhet, men også fordi barnet vil kunne få et godt gentestsvar. En genetisk veiledning vil kunne hjelpe familien og barnet med å klargjøre problemstillingene, og gi kunnskap nok til at familien kan fatte sine egne beslutninger i denne forbindelse.

\section{OPPSØKENDE GENETISK INFORMASJONSVIRKSOMHET}

Oppsøkende genetisk informasjonsvirksomhet er regulert i bioteknologiloven § 5-9 (ramme 3). Av alle paragrafer i loven, er dette den lengste og mest omstendelige, trolig også den som er vanskeligst å forstå. Det skyldes at det er to etiske hensyn som bioteknologiloven forsøker å balansere - personvernet og privatlivets fred. Vi skal kort skissere hvordan oppsøkende genetisk informasjonsvirksomhet forutsetter hensyntaken til begge verdiene.

\section{Ramme 3}

OPPS $\varnothing K E N D E$ GENETISKE INFORMASJONSVIRKSOMHET I HENHOLD TIL BIOTEKNOLOGILOVEN (1)

- §5-9. Oppsøkende genetisk informasjonsvirksomhet

- Med oppsøkende genetisk informasjonsvirksomhet forstås i denne loven helsepersonells adgang til å informere pasientens berørte slektninger om arvelig sykdom i familien.

- Når det er dokumentert at en pasient har eller er disponert for en arvelig sykdom, bestemmer pasienten selv om han eller hun vil informere berørte slektninger om dette.

- Dersom pasienten ikke selv kan eller vil informere berørte slektninger, kan helsepersonell be om pasientens samtykke til å informere disse, hvis vilkårene i femte ledd er oppfylt og sykdommen er godkjent av departementet etter sjuende ledd. - Dersom pasienten ikke kan samtykke til at helsepersonell informerer berørte slektninger, kan helsepersonell i særlige tilfeller gjøre dette, hvis vilkårene i femte ledd er oppfylt og sykdommen er godkjent av departementet etter sjuende ledd.

- Før helsepersonell tar kontakt med slektningene, skal han eller hun vurdere om: 
1. det gjelder en sykdom med vesentlige konsekvenser for den enkeltes liv eller helse,

2. det er en rimelig grad av sannsynlighet for at også slektningene har et arvelig sykdomsanlegg som kan føre til sykdom senere i livet,

3. det foreligger en dokumentert sammenheng mellom det arvelige

sykdomsanlegget og utvikling av sykdom,

4. de genetiske undersøkelser som benyttes for å fastslå det arvelige

sykdomsanlegget, er sikre, og

5. sykdommen kan forebygges eller behandles med god effekt.

- Dersom slektningen er under 16 år, skal bare foreldrene eller andre med

foreldreansvar informeres.

- Departementet bestemmer i forskrift eller i det enkelte tilfelle hvilke sykdommer som kan gjøres til gjenstand for oppsøkende genetisk virksomhet.

Hovedregelen kan sies å være at all oppsøkende informasjonsvirksomhet er forbudt, såfremt pasienten ikke samtykker til det (og vi har å gjøre med en pasient som i prinsippet kan samtykke). Dette gjelder uansett sykdommens alvorlighetsgrad eller behandlingsmuligheter. Så lenge pasienten motsetter seg at helsepersonell kontakter familiemedlemmer, kan dette ikke finne sted. Pasientens samtykke er altså en nødvendig betingelse. En rimelig fortolkning av loven er at dette understreker legens absolutte taushetsplikt overfor pasienten, og dermed beskyttelsen av personvernet til pasienten. Samtykker ikke pasienten, er det forbudt for legen å gå bak ryggen på pasienten med sensitiv sykdomsinformasjon.

Pasientens samtykke er altså ikke en tilstrekkelig betingelse for at helsevesenet kan gjøre oppsøkende genetisk informasjonsvirksomhet. Det betyr at selv om en pasient ønsker og har samtykket $i$ at helsevesenet tar kontakt med slektninger for å informere dem om arvelig risiko, så er det ikke automatisk tillatt. For ikke å krenke privatlivets fred, skal lege først vurdere sykdommens alvorlighetsgrad og behandlingseffekt ut fra fem tilleggskriterier i bioteknologiloven (ramme 3). I tillegg må departementet godkjenne sykdommen for oppsøkende genetisk informasjonsvirksomhet.

Her ser man at det ikke lenger er taushetsplikten som er relevant. Pasienten har fritatt legen for denne. Når det likevel er slike strenge restriksjoner, må dette fortolkes som en hensyntaken til slekt. Helsevesenets oppgave er neppe å uroe og medikalisere mennesker som opplever seg som friske og som ikke selv har tatt kontakt med helsevesenet. Det kan generelt sies å være et utillatelig inngrep i privatlivets fred. Imidlertid kan det tenkes situasjoner hvor man må kunne anta at ethvert fornuftig menneske ville ønske å bli oppsøkt av helsevesenet fordi det står om liv og det finnes behandlingsmuligheter. Slik som i vår kasuistikk hvor avklaring av kvinnens mutasjonsstatus kunne si noe om det var særlige hensyn som måtte tas med tanke på adekvat oppfølging av den gravide under fødselen og postpartumtiden. Og det er kun i slike situasjoner at det ifølge loven vil være aktuelt å sette til side hensynet til privatlivets fred.

I 2002 hadde Helsedepartementet et utkast til forskrift om oppsøkende genetisk informasjonsvirksomhet på høring. I dette utkastet kunne man finne lang QT-syndrom som en av sykdommene man vurderte som aktuell for oppsøkende genetisk informasjonsvirksomhet. Forskriften trådte imidlertid ikke i kraft. I dag finnes det ingen forskrift fra departementet om hvilke genetiske sykdommer som kan gjøres til gjenstand for slik informasjonsvirksomhet. Myndigheten til å avgjøre i «det enkelte tilfelle» er nå delegert til Sosial- og helsedirektoratet. Men direktoratet er ikke kjent med at det har vært noen søknader om godkjenning etter $\S 5-9$ (personlig meddelelse, Anne Forus, Helsedirektoratet 1.4.2009). I praksis betyr dette at oppsøkende genetisk informasjonsvirksomhet i forhold til lang QT-syndrom foreløpig ikke er mulig, selv om 
pasienten samtykker. En søknad om godkjenning, må først forelegges Helsedirektoratet. Da vil vi få vite om helsevesenet i Norge får lov til å oppsøke slektninger og informere om arvelig risiko, gitt at pasienten med lang QT-syndrom har samtykket til dette.

\section{Konklusjon}

Den norske bioteknologiloven kan sies å understreke betydningen av den genetiske veiledningssamtalen. Genetisk veiledning skal være en prosess, og bioteknologiloven sikrer denne prosessen ved at det gis genetisk veiledning både før, under og etter at undersøkelsen er foretatt, og den regulerer genetisk testing av barn. På den måten legges det grunnlag for at informasjonen kan bearbeides og forstås og at pasientene gis mulighet til å mestre. Samtidig setter loven strenge krav til taushetsplikt og hensynet til privatlivets fred. Det kan stilles spørsmål om loven går for langt i å begrense muligheten for oppsøkende genetisk informasjonsvirksomhet i forhold til en arvelig sykdom som lang QTsyndrom. Helsegevinsten av å kjenne til sin risikosituasjon kan være betydelig. Om loven er for restriktiv, kan man imidlertid ikke svare på i dag. Det skyldes at myndighetene på det nåværende tidspunkt ikke har tatt stilling til om lang QT-syndrom kan være en sykdom som kvalifiserer for oppsøkende genetisk informasjonsvirksomhet.

\section{Oppgitte interessekonflikter:}

Ingen

\section{Tabell}

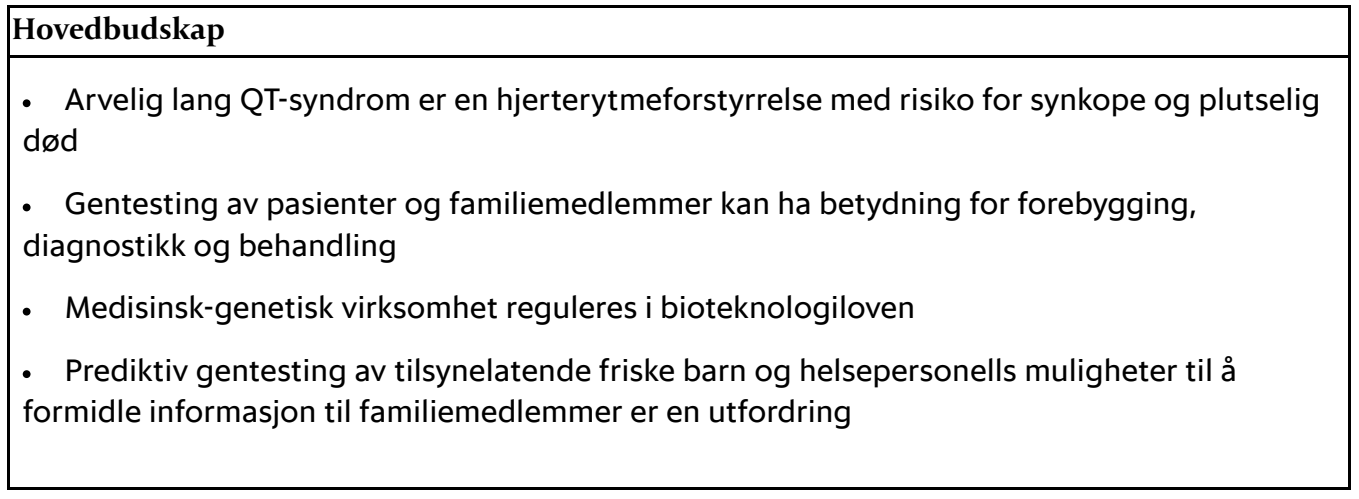

\section{LITTERATUR}

1. Lov om humanmedisinsk bruk av bioteknologi m.m. (bioteknologiloven) av 12.mai 2003 og endringer av 2004-09-01.

2. Jervell A, Lange Nielsen F. Congenital deaf-mutism, functional heart disease with prolongation of the Q-T interval and sudden death. Am Heart J 1957; 54: 59-68.

3. Romano C, Gemme G, Pongiglione R. Aritmie cardiache rare dell"eta. Clin Pediatr 1963; 45: 656-83.

4. Ward OC. A new familial cardiac syndrome in children. J Ir Med Assoc 1964; 54: 103-6.

5. Roden DM. Clinical practice. Long-QT syndrome. N Engl J Med 2008; 358: 169-76. 
6. Modell SM, Lehmann MH. The long QT syndrome family of cardiac ion channelopathies: a HuGE review. Genet Med 2006; 8: 143-55.

7. Zipes DP, Camm AJ, Borggrefe M et al. ACC/AHA/ESC 2006 guidelines for management of patients with ventricular arrhythmias and the prevention of sudden cardiac death: a report of the American College of Cardiology/American Heart Association Task Force and the European Society of Cardiology Committee for Practice Guidelines (Writing Committee to Develop guidelines for management of patients with ventricular arrhythmias and the prevention of sudden cardiac death) developed in collaboration with the European Heart Rhythm Association and the Heart Rhythm Society. Europace 2006; 8: 746-837.

8. Schwartz PJ, Moss AJ, Vincent GM et al. Diagnostic criteria for the long QT syndrome. An update. Circulation 1993; 88: 782-4.

9. Berge KE, Haugaa KH, Anfinsen OG et al. DNA-based diagnostics of long QT syndrome Tidsskr Nor Lægeforen 2005; 125: 2783-6.

10. Priori SG, Bloise R, Crotti L. The long QT syndrome. Europace 2001; 3: 16-27.

11. Hobbs JB, Peterson DR, Moss AJ et al. Risk of aborted cardiac arrest or sudden cardiac death during adolescence in the long-OT syndrome. JAMA 2006; 296: 1249-54.

12. Sauer AJ, Moss AJ, McNitt S et al. Long QT syndrome in adults. J Am Coll Cardiol 2007; 49:329-37.

13. Priori SG, Schwartz PJ, Napolitano C et al. Risk stratification in the long-QT syndrome. N Engl J Med 2003; 348: 1866-74.

14. Moss AJ. Prolonged QT-interval syndromes. JAMA 1986; 256: 2985-7.

15. Moss AJ, Zareba W, Hall WJ et al. Effectiveness and limitations of beta-blocker therapy in congenital long-QT syndrome. Circulation 2000; 101: 616-23.

16. Seth R, Moss AJ, McNitt S et al. Long QT syndrome and pregnancy. J Am Coll Cardiol 2007; 49: $1092-8$.

17. Zipes DP, Camm AJ, Borggrefe M et al. ACC/AHA/ESC 2006 Guidelines for Management of Patients With Ventricular Arrhythmias and the Prevention of Sudden Cardiac Death: a report of the American College of Cardiology/American Heart Association Task Force and the European Society of Cardiology Committee for Practice Guidelines (writing committee to develop Guidelines for Management of Patients With Ventricular Arrhythmias and the Prevention of Sudden Cardiac Death): developed in collaboration with the European Heart Rhythm Association and the Heart Rhythm Society. Circulation 2006; 114: e385-e484.

18. Resta R, Biesecker BB, Bennett RL et al. A new definition of genetic counseling: National Society of Genetic Counselors" Task Force Report. J Genet Couns 2006; 15: 77-83.

19. Khan IA. Long QT syndrome: diagnosis and management. Am Heart J 2002; 143: 7-14.

20. Vincent GM. The long-QT syndrome-bedside to bench to bedside. N Engl J Med 2003;348: 1837-8.

Publisert: 11. juni 2009. Tidsskr Nor Legeforen. DOI: 10.4045/tidsskr.09.32621

Manuskriptet ble mottatt 21.1. 2008 og godkjent 16.4. 2009. Medisinsk redaktør Erlend Hem.

(C) Tidsskrift for Den norske legeforening 2023. Lastet ned fra tidsskriftet.no 26. april 2023. 